\title{
CHILDREN AND POOR CITY IN MEDAN
}

\author{
Dede Ruslan $^{1 *}$, Andi Bahar², Mangatas Pasaribu ${ }^{3}$ \\ ${ }^{1}$ Department of Bussiness Administration Education, Faculty of Economics, Medan State University, Medan, \\ Indonesia \\ ${ }^{2}$ Machine Major, Faculty of Engineering, Medan State University, Medan, Indonesia \\ ${ }^{3}$ Art Study Program, Faculty of Languages and Arts, Medan State University, Medan, Indonesia \\ *Corresponding Author: dras_ruslan@yahoo.com
}

\begin{abstract}
IbM program activities are aimed to help street children and poor cities that are assisted by SKA and PKPA in developing skill-based life skills education. Operationally this activity aims to help street children and urban poor in production. Types of production that have been done, among others, make various handicrafts from beads and acrylic, and packaging products Marginal Industry House. Methods of activities in the form of training and mentoring in production practices, packaging design practices, business management training and practice of machine use. Targets that have been implemented from IbM activities are: 1) The existence of various products of beads and acrylics, 2) The existence of cutting tools of sweet potatoes and bananas, 3) The existence of RIM'S design that attract and support the product selling value, 4) withdraw from each product and 5) The existence of simple bookkeeping and financial statements.
\end{abstract}

Keywords: Street Children and Poor City, Multifarious Crafts, Cassava and Banana Cutting Tools, Packaging Design

\section{INTRODUCTION}

Children Creativity Center (SKA) and Child Protection Study Center (PKPA) is an institution concerned with poverty eradication in Medan focusing on empowering street children and urban poor. To empower street children and urban poor, SKA works together with PKPA to build shelters located at Pinang Baris Sub-district of Medan City. Currently there are 318 street children who are assisted by SKA. The number of 318 people consisted of children as many as 250 people and adults as many as 68 people. While viewed from the gender of 318 people consisted of 169 men and 149 women. Of these, data from PKPA show that 60\% of street children are still in school but at risk of dropping out and $40 \%$ are children who Karena mereka terbiasa berkumpul di tempat bilyard, penghasilan mereka pun akhirnya digunakan juga untuk judi bilyard, bukan dibawa pulang untuk memenuhi kebutuhan makan keluarga atau setidaknya untuk memenuhi kebutuhan makan mereka sendiri. have dropped out of school and never attended school.

Most street children assisted by SKA daily gathered in billiard places, at the terminal and at the intersection of the road around Pinang Baris Subdistrict. Economically, they come from poor and very poor families with parental income that is not fixed. They gathered at a billiard place in the hope of working as a servant in return for Rp 15,000 , - a day. In addition they gather at the terminal to find work as a sweeper bus and city transportation in return $\mathrm{Rp} 3,000$, - to $\mathrm{Rp} 5,000$, - or wash vehicles in return $\mathrm{Rp} 10.000$, -. While at the intersection of the road, they work as street singers, cigarette sellers, shoe shineers with an average income of Rp 15.000, -. Although they work and earn income but psychologically their lives are vulnerable to social problems. The environment in which they gather and work greatly influences his behavior and lifestyle. Because they are used to gathering in billiards, their income is eventually used for gambling bilyards, rather than being brought home to meet the needs of family meals or at least to meet their own eating needs. Likewise those who gather at the terminal and intersection. Their income is also not used to meet family needs but is used for gambling, smoking, ngelem (suck glue) and even there to buy marijuana or drugs. This condition is actually already known by their parents, but because economically parents are not able to meet the needs of a decent life for them, then parents choose not to care about the issue is important they do not disturb their neighborhood.

The phenomenon indicates that not a few children who do not get a decent school opportunity and even lost the opportunity to school. This phenomenon can not be tolerated. If this problem is not addressed immediately, it is feared will lead to poverty, ignorance, and sustainable backwardness. To raise or alleviate the problem of drop-out children requires a life skill education model (life skills) that match their interests, talents, and skills. Life skills education by definition is: the education of various skills or ability to adapt and behave positively, enabling one to 
be able to face the various demands and challenges in everyday life effectively (UN-WHO, 2009). It is urged to be examined as part of the moral responsibility for the future of Indonesian children. Through the mastery of life skills, it is expected that street children and urban poor are able to earn their own income that can support themselves and their families so that they can get out of poverty, backwardness, and ignorance.

One effort to solve the problem has been done by SKA in cooperation with PKPA Medan City. SKA (Part I) in cooperation with PKPA (Partner II) Medan City has built a shelter house as a place to support the development of children, especially access to education. SKA acts as a shelter manager located in Pinang Baris while PKPA facilitates SKA skyscraper activities by preparing teachers, instructors and companions. In addition PKPA also facilitate a place to sell the products of street children assisted SKA with the name of Industrial House Marginal (RIM) with RIM'S label.

Street children and poor cities assisted by SKA come to the shelter home for alternative education and skills. Of the hundreds of street children who become assisted, generally they go home. Therefore, SKA also implement the Home Capacity program (Household Strengthening). In this abandoned house, street children got the skills to grow hydroponics, make various products from used goods, skill of making lanterns from wool yarn, sewing skills and making graduation dolls for street girls, as well as the skill of making liquid fertilizer and, making various chips and snacks for drop out children.

This assistance program is very intensive and scheduled considering the location of the shelter near the Pinang Baris terminal area, if the assistance is not done in discipline they will return to the location and re-assemble with the environment consequently they will experience a decrease in motivation and encounter social barriers in the school environment.

Economically, street children's products and miskisn kota niaasn SKA and PKPA have been sold and marketed through RIM'S prepared by PKPA. But the types of products that can be produced or manufactured by street children and poor cities with SKA are still very limited. This is due to their knowledge and skills in production. In addition, the assistance of instructors and assistants for product development is also very dependent on PKPA because PKPA is responsible for preparing instructors and their education and skills counselors. While PKPA itself as a non-profit institution, the procurement of instructors as well as education and skill companions is highly dependent on sponsors and other parties' assistance as well as government programs. In this case PKPA always looking for sponsors and assistance from third parties such as business and industry, Department of Social Affairs, Department of Education, Department of Labor and other agencies to get funding. Funds obtained are ultimately used to develop educational programs in SKA.

In addition to the limited capital and human resource skills in producing goods as mentioned above, the problem faced by SKA is that it does not have the equipment primarily to produce snacks such as onion cakes, banana chips, sweet potato chips and other snacks. In production, they still do it traditionally with simple equipment without a touch of appropriate technology. As an illustration, the number of their banana chips and cassava chips production in ten days averages 8 to $10 \mathrm{~kg}$. while the number of requests in a week to reach $10-12 \mathrm{~kg}$. The process production has done in their homes rather than in SKA. In producing them assisted by parents and family. Due to equipment limitations, they can't fulfill the request.

From the marketing management aspect, the limitations faced by the partners are the packaging aspect. The product has not been packaged properly, so it is less attractive and does not support the selling point of the product. When packaged properly will surely increase the value of selling products and will raise the image of RIM'S brand as a food store and store products of the work of street children and city poor managed professionally.

Based on the analysis of the situation mentioned above, several obstacles and problems in managing the production business conducted by street children and poor cities with SKA in cooperation with PKPA are as follows:

1. The low ability and skill of human resources in SKA or PKPA in producing various handicrafts so that the kind of handicraft products produced by street children and urban poor is very limited.

2. Unavailability of instructors, assistants and permanent teachers on SKA and PKPA resulted in the production of street children and urban poor not varied or stagnant / roads in place. This will result in their decreased motivation.

3. The low ability and skill in producing various chips and snacks result in low production volume $(24-30 \mathrm{~kg}$ / month) while the average demand reaches 40 - $48 \mathrm{~kg} /$ month.

4. Not having the production equipment of cassava or banana cutters cause the production capacity can't fulfill the demand

5. There are already labels for RIM'S (Marginal Industrial House) but not yet well designed. 6. The product packaging is still very traditional so it is not attractive and yet support the selling value of the product. 
6. Management is not well managed, production cost and unit cost has not been calculated operationally so it can't be calculated profit / loss.

\section{METHOD OF IMPLEMENTATION}

Based on the problems that have been raised, then in this activity IbM implementation method used, namely:

1. Education and training of making various products of beads and acrylic

2. Simulation of the use of sweet potato and banana cutter.

3. RIM'S packaging design education and training are interesting.

4. Business management education and training.

\section{RESULTS AND DISCUSSION}

1. Education and Training of Business Management

Education and business management training conducted on July 04, 2017. In business management training is the delivery of materials about the management of business management seen from the business management functions of Planning, Organizing, Direction and Supervision in managing businesses such as managing human resources or group teams owned businesses, how to manage the resources or materials used and SOPs in production

2. Education, Training and Production Practice

Production skills education and training is conducted for three stages on 11, 12 and 18 July 2017 . The implementation process, namely:

A. Phase I Training

Making spongebob sponge and sponge marks on July 11, 2017. The process undertaken at this stage, namely:

1) Submission of materials by the instructor delivered by Mrs. Yuni.

2) Practice of making key toy accessories and spongebob shaped spot. At this stage is expected children Children Creativity Studio can make accessories making so as to increase income SKA or Marginal Industry House. Here are the details of the funds needed in making accessories and benefits obtained from the sale of accessories.

a. Toy Accessories / Key Chain, production cost of Rp. 3,000 and the selling price of Rp. 5,000 so profit per unit of Rp. 2,000. In one day per person can finish the product as much as 5 pieces so the profit generated in one day amounted to Rp. 10,000 and a month can earn a profit of Rp. 300,000 per person.

b. Spongebob-shaped Pencil Accessories, production cost of Rp. 6,500 and the selling price of Rp. 10,000 so profit per unit of Rp. 3,500. In one day per person can finish the product as much as 3 pieces so the profit generated in one day amounted to Rp. 10,500 and a month can earn a profit of Rp. 315,000 per person.

\section{The following documentation of activities in the process of making} key toy accessories and spongebob shaped spot.

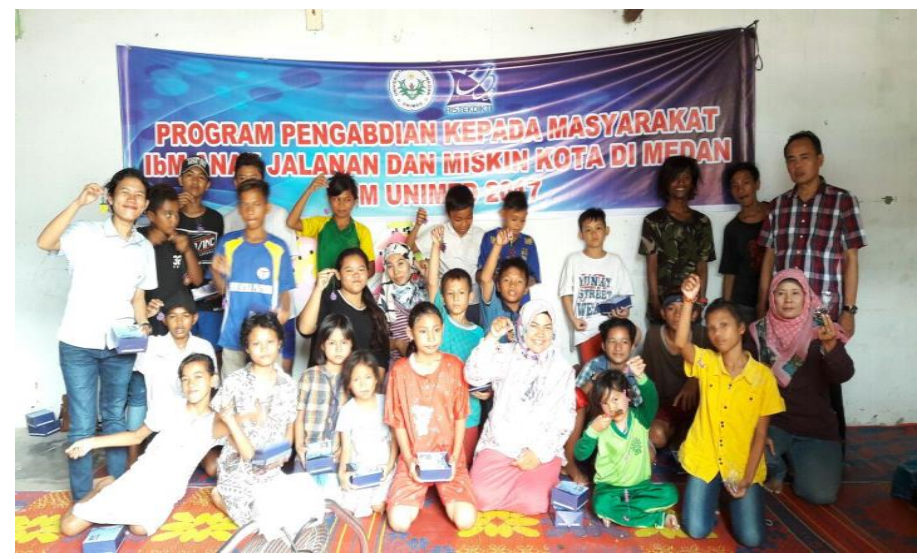

B. Phase II Training

The manufacture of flower accessories stalk on July 12, 2017. The process undertaken at this stage, namely:

1) Submission of materials by the instructor delivered by Mrs. Yuni.

2) Practice of making flower stalk accessories. At this stage is expected to be able to increase the group's income. Here are the details of the funds needed in making flower accessories stalks and the benefits obtained from the results penjulan accessories. 
- Flower Accessories Stalk, production cost of Rp. 5,000 per stalk and the selling price of Rp. 8,000 so profit per unit of Rp. 3,000. In each day per person can finish the product as much as 4 pieces so that the profit generated in each day is Rp. 12,000 and a month can earn a profit of Rp. 360,000 per person.

Here is the documentation of activities in the process of making stalk flower accessories.

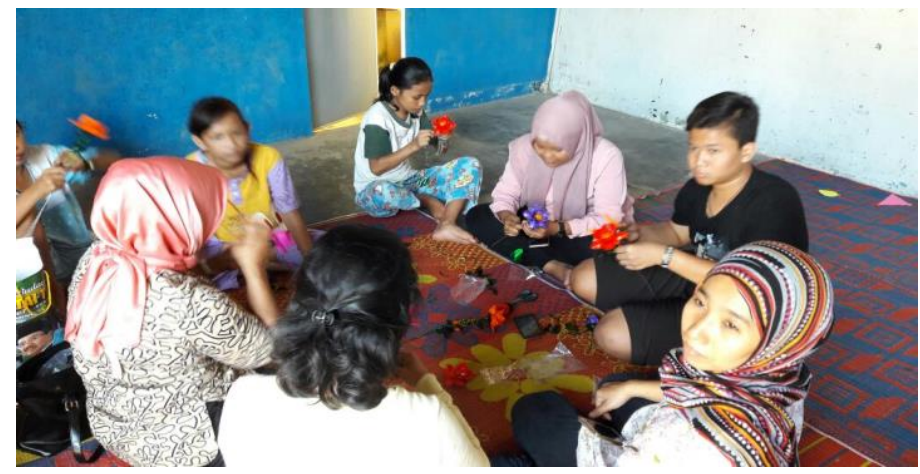

Flower Arrangement Process

C. Training Phase III

Making of tissue box accessories and practice of using cassava irrigation tool on August 9, 2016. The process undertaken at this stage, namely:

1) Submission of materials by instructors delivered by Mrs. Eka Kuswardani and Mrs. Julia Wanda

2) Practice of making the place tissue accessories. At this stage is expected to increase the group's income. Here are the details of the funds needed in making accessories and benefits obtained from the sale of accessories.

- Place Tissu, production cost of Rp. 17,500 and the selling price of Rp. 30,000 so profit per unit of Rp. 12,500. In every day per person can finish the product where tissu as much as 1 fruit so that the profit generated in each day is Rp. 12,500 and a month can earn a profit of Rp. 375,000 per person.

3) Tool Usage Practices. This activity is done by simulating the use of cassava slicer as well as handover of cassava slicer. However, training is first done to the Mothers how to use the tool and the maintenance of the tool. This activity is expected to help mothers in production especially cassava or banana slicing process.

The following is documentation of activities in the process of making the Tissu Place accessory and the practical process of using tools.

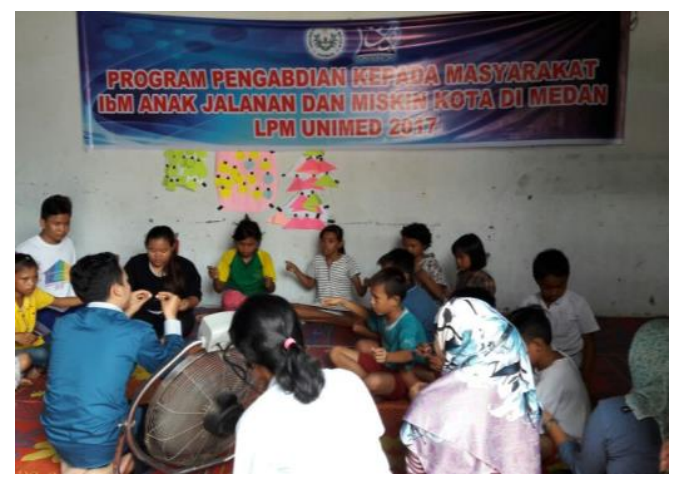

Practice Making Tissue venue

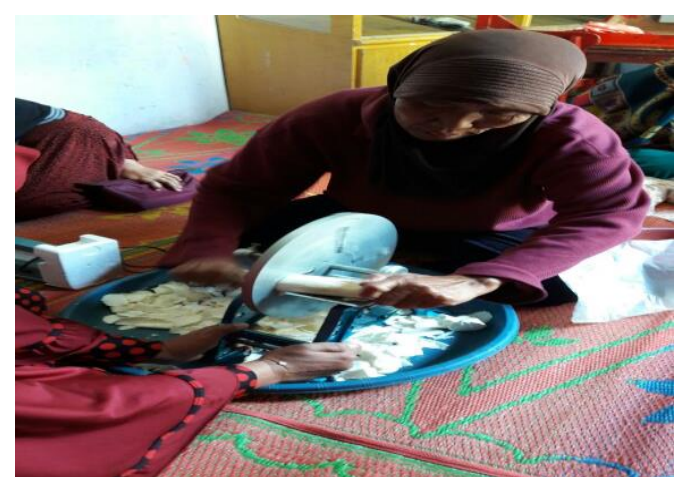

Practice of Using Cassava Slicer

3. Product Packaging Practice Training

Training on product packaging practices conducted on July 25, 2017. The process of implementation of its activities, namely:

a) Submission of activity materials on how to design the packaging of processed products to make it look attractive so that consumers want to buy it. 
b) Submission of material on exposure and discussion on the use of information technology and social media in optimizing the marketing of products produced by the partner business group.

c) Practice packaging of products with new packaging design and use bag sealer.

\section{The following is the documentation of the process of training activities on packaging practices of RIM'S processed products}
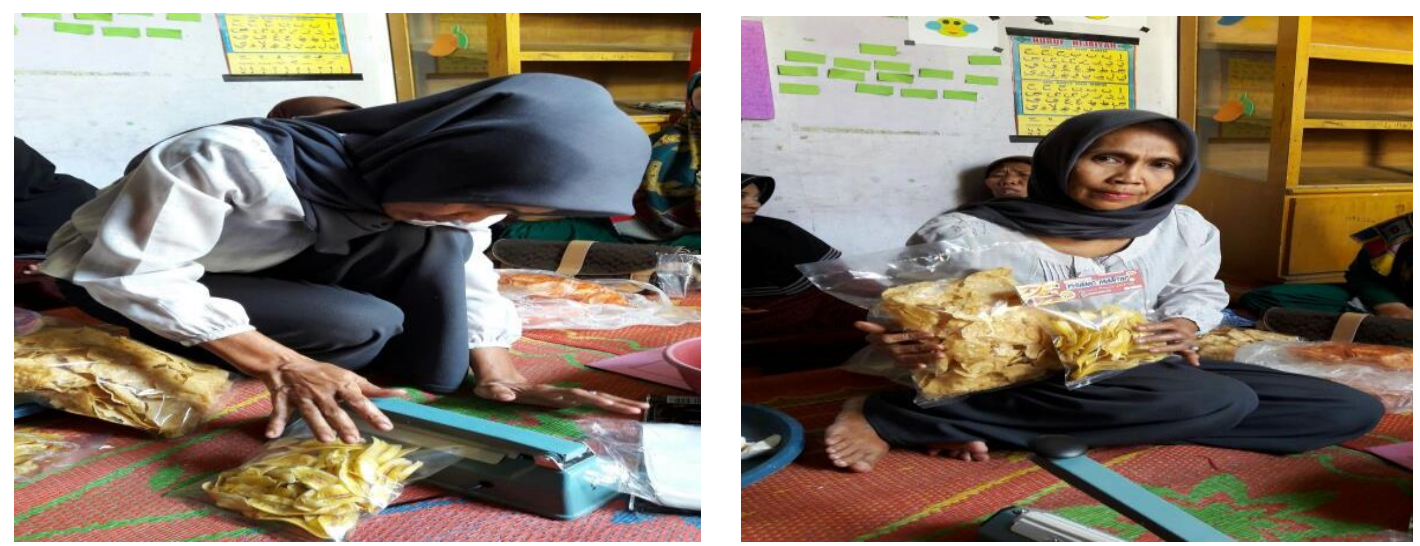

Practice Packaging with New Labels

4. Training of Financial Report Preparation

Education and training of financial bookkeeping of MSMEs conducted on July 26, 2017. In improving the professional business group, the implementing team also equip the Mothers of the SKA-PKPA target group, especially the Marginal Industry House manager on how to manage finances simply by lecture method, discussion and practice directly in making financial reports. It is expected that with this training, RIM'S group is able to make production cost, balance sheet, profit and loss statement, and simple financial report.

\section{CONCLUSION}

Based on the results of program activities IbM Street Children and the Urban Poor in the field that have been implemented, it can be concluded that the Group of SKA-PKPA and Home Industry Marginal able to create innovative products or skill in making accessories toys key, the pencil-shaped spongebob, flower stalk, a tissue holder and can use a cassava slicer to increase the production and packaging of RIM'S products.

Suggestion that can be delivered in this activity is expected existence of program of service to society which can be implemented similar program in other area which have potential to be accompanied and given new skill or other program. Thus, it will be able to provide broader benefits in support of government programs to overcome poverty and can improve the welfare of people in Indonesia. 